Canadian Journal of Soil Science Revue canadienne de la science du sol

\title{
Soil microbial properties during decomposition of pulse crop and legume green manure residues in three consecutive subsequent crops
}

\begin{tabular}{|r|l|}
\hline Journal: & Canadian Journal of Soil Science \\
\hline Manuscript ID & CJSS-2016-0039.R1 \\
\hline Manuscript Type: & Article \\
\hline Date Submitted by the Author: & $17-$ May-2016 \\
\hline Complete List of Authors: & $\begin{array}{l}\text { Lupwayi, Newton; Agriculture and Agri-Food Canada, } \\
\text { Soon, Yoong; Agriculture \& Agri-Food Canada }\end{array}$ \\
\hline Keywords: & $\begin{array}{l}\text { Microbial activity, Microbial biomass, Soil biology, Crop residue, Crop } \\
\text { rotation }\end{array}$ \\
\hline \multicolumn{2}{|l}{} \\
\hline
\end{tabular}

SCHOLARONE ${ }^{m}$

Manuscripts 
Soil microbial properties during decomposition of pulse crop and legume green manure residues in three consecutive subsequent crops

\author{
Newton Z. Lupwayi ${ }^{1^{*}}$ and Yoong K. Soon ${ }^{2}$ \\ ${ }^{1}$ Agriculture and Agri-Food Canada, Lethbridge Research Centre, P.O. Box 3000, Lethbridge, Alberta, T1J \\ 4B1, Canada; ${ }^{2}$ Agriculture and Agri-Food Canada, Beaverlodge Research Farm, P.O. Box 29, Beaverlodge, \\ Alberta, TOH OCO, Canada. \\ *Corresponding author, email: newton.lupwayi@agr.gc.ca; Tel.: +1-403-317-3315, Fax: +1-403-382- \\ 3156.
}


Crop residue decomposition is mainly driven by, but also affects, soil microorganisms. However, soil microbial responses to legume crops are usually studied only in one subsequent crop. We compared the soil microbial effects of pea (Pisum sativa L.) and faba bean (Vicia faba L.) pulse crops (grown for seed) with faba green manure (GM) and chickling vetch (Lathyrus sativus L.) GM crops in three subsequent crops. Soil microbial biomass $\mathrm{C}(\mathrm{MBC}), \beta$-glucosidase enzyme activity and bacterial physiological (C substrate utilization) diversity were measured in the summer (rhizosphere and bulk soil) and fall (bulk soil) in all subsequent crops: wheat (Triticum aestivum L.), canola (Brassica napus L.) and barley (Hordeum vulgare L.). Residues of faba bean (grown for GM, herein called Faba GM, or for seed, herein called Faba bean) usually resulted in the most soil $\mathrm{MBC}$ and $\beta$-glucosidase activity relative to the other residues. Faba and vetch $\mathrm{GM}$ residues increased bulk soil $\mathrm{MBC}$ or $\beta$-glucosidase enzyme activity more than pulse crop residues in the first and/or third subsequent crops. Soil MBC and $\beta$-glucosidase activities were often positively correlated with initial crop residue $\mathrm{N}$ concentrations and negatively correlated with initial C: $\mathrm{N}$ ratios or $\mathrm{C}$ concentrations. Bacterial physiological diversity was the least responsive to crop residues, and was affected differently by sampling time. $\beta$-glucosidase activity was always greater in the fall after crop harvest than in summer. Therefore, $\beta$-glucosidase activity was a more sensitive and consistent biological indicator of crop residue effects, and perhaps soil health, than $\mathrm{MBC}$ or bacterial physiological diversity.

Keywords: Crop rotation, soil microbial biomass, $\beta$-glucosidase activity, pulse crops, green manure.

Abbreviations: ae, acid equivalent; ai, active ingredient; ANOVA, analysis of variance; CLPP, communitylevel physiological profile; Faba bean, faba bean grown for seed (harvested at seed maturity); Faba GM, faba bean grown for green manure (cut at flowering stage); GM, green manure; $\mathbf{H}^{\prime}$, Shannon index of 
diversity; MBC, microbial biomass C; MVSP, Multi-Variate Statistical Package; PCA, principal component analysis; RCBD, randomized complete block design.

\section{INTRODUCTION}

In studying the rotational benefits of pulse crops to subsequent nonlegume crops, it is important to examine changes in soil microbial properties because decomposition of crop residues is mostly mediated by soil microorganisms, especially bacteria and fungi. Because crop residues contain 40 to 46\% C (Blanco-Canqui and Lal 2009), returning them to the soil adds C to the soil stocks. Soil organic C content is a very important soil health factor that influences soil physical, chemical, and biological properties that contribute to soil productivity. Heterotrophic soil microorganisms depend on soil organic C for their cellular growth and energy. Therefore, decomposition of crop residues, and its concomitant recycling of nutrients, is likely not only to affect, but also be affected by, soil microorganisms. In a 3-year field decomposition study in a semi-arid region of Argentina, Araujo et al. (2012) demonstrated that the exclusion of soil fauna had no effect on grass litter decomposition, but reduction of fungal colonization on the litter reduced the loss of litter mass. Deng and Tabatabai (1996) reported that, relative to bare soils or soils with normal maize (Zea mays, L.) residue amounts in a no till system, soils that received double the amount of residues had higher activities of $\alpha$ - and $\beta$-glucosidase enzymes. Similar C-related effects of crop residues on soil MBC, arylesterase and $\beta$-glucosidase enzyme activities were observed by Moreno-Cornejo et al. (2013).

For legume crop residues, the cycling of the $\mathrm{N}_{2}$ that they fix is a major factor in their rotational benefits to subsequent nonlegume crops. During residue decomposition, organic $\mathrm{N}$ in the residues is converted to inorganic $\mathrm{N}$ that becomes available for plant uptake. The $\mathrm{N}$ contained in the decomposing crop residues will affect their colonization by soil microorganisms (Pascault et al. 2010), and the $\mathrm{N}$ released during decomposition will affect soil microorganisms (Lupwayi et al. 2004; Partey et al. 2014). The N, P or K contents of residues of red clover (Trifolium pretense L.) GM, field pea, canola (Brassica 
rapa L.), wheat and barley were positively correlated with soil microbial activity $\left(\mathrm{CO}_{2}\right.$ evolution) and physiological diversity (based on C substrate utilization) either in a 12-month field study or a greenhouse incubation study (Lupwayi et al. 2004). In a 11-month field study of the colonization of wheat, rape (Brassica napus L.) and alfalfa (Medicago sativa L.) residues by soil microorganisms, Pascault et al. (2010) found that colonization by proteobacteria depended on the initial biochemical quality of the residues, with the highest abundance observed on alfalfa residues ( $C: N$ ratio $27: 1$ ) and lowest on wheat residues (C:N ratio 94:1). A laboratory incubation study showed similar $\mathrm{N}$-related effects of crop residue quality on soil $\mathrm{N}$ mineralization, $\mathrm{MBC}$ and $\mathrm{C}$ mineralization as they were all greater in soils that received $\mathrm{GM}$ residues of faba bean and Tithonia diversifolia, either alone or in combination with maize residues, than in soils that received only maize residues (Partey et al. 2014).

In the Canadian prairies, it is recommended that a pulse (grain legume) crop be grown not more than once every four years (Saskatchewan Pulse Growers 2011). The crops that are often grown in 4year rotations with pulse crops are wheat, canola (Brassica napus L. or B. rapa L.) and barley (Statistics Canada 2014). However, in most studies about legume effects on soil microorganisms, including the studies described above (Lupwayi et al. 2004; Pascault et al. 2010; Partey et al. 2014), soil microbial response is determined in only one season, part of a season, or in short-term incubations. The soil microbial responses over the full course of a normal crop rotation are usually not evaluated. In this study, soil microbial biomass, diversity and enzyme activity were determined in three consecutive crops grown after pulse and GM legumes. All these soil microbial properties are important biological indicators of soil health (Doran and Safley 1997). We hypothesized that aboveground residues of pulse crops would have different N-related effects from legume GM crops on soil microbial properties, and that belowground residues (estimated by removing aboveground residues) would also contribute to these effects. The specific objectives of the study were (a) to determine the effects of aboveground residues of pea, faba bean, faba $G M$ and vetch $G M$ on soil $M B C, \beta$-glucosidase enzyme activity and the 
physiological diversities of bacteria in three consecutive crops grown after the legumes, and (b) to examine the contribution of belowground residues (by removal of aboveground residues) to these responses. The $\mathrm{C}$ and $\mathrm{N}$ release patterns of the residues over the three consecutive subsequent crops, and the responses of the rotation crops to the legume residues, have been reported elsewhere (Lupwayi et al. 2015 and 2016).

\section{MATERIALS AND METHODS}

\section{Treatments and Experimental Design}

Four-year rotations were established at Beaverlodge $\left(55.2^{\circ} \mathrm{N}, 119.4^{\circ} \mathrm{W}\right)$, Alberta, Canada in 2007 on land that had previously been uniformly grown to oats (Avena sativa, L.). The soil was an Albright Silt Loam Dark Grey Luvisol with the following properties in the $0-15 \mathrm{~cm}$ layer at initiation of the study: pH(water) 6.3, 22 g organic C, $0.5 \mathrm{mg} \mathrm{CaCl}_{2}$-extractable $\mathrm{N}, 7 \mathrm{mg} \mathrm{NaHCO}{ }_{3}$-extractable $\mathrm{P}, 310 \mathrm{mg} \mathrm{\textrm {NaHCO } _ { 3 } -}$ extractable $\mathrm{K}$, and $1.3 \mathrm{mg} \mathrm{CaCl}_{2}$-extractable $\mathrm{S}$ per $\mathrm{kg}$ soil. The first year of the rotations consisted of two pea types: green pea and forage pea, with aboveground residues retained or removed, faba bean grown for seed, faba GM, chickling vetch GM and hulless barley (Table 1). Aboveground pea residues were removed in some treatments to estimate the effects of belowground residues. The green pea variety, Camry, was a semi-leafless type, and the forage pea variety, 4010, was a bushy normal-leafed type. The amounts and quality of these residues were published by Lupwayi and Soon (2015). These crops were followed by wheat in 2008, canola in 2009 and hulless barley in 2010. Barley was also grown in 2007 as a control. The pea treatments were arranged in a split-plot design, where pea type was the main plot treatment and residue removal was the sub-plot treatment. Each plot was $11 \mathrm{~m}$ long and $3.7 \mathrm{~m}$ wide. The rest of the treatments (Treatments 5 to 8, Table 1) were arranged in randomized complete block design (RCBD) with four replicates. All the crops were managed under no-till. 


\section{Seeding Legumes and Barley in 2007}

Crops in 2007 (the legume year) were seeded on 1 June in rows $23 \mathrm{~cm}$ apart. Pre-seeding burn-off (weed control) with a herbicide was not necessary. Seeding rates were $225 \mathrm{~kg} \mathrm{ha}^{-1}$ for green pea, $119 \mathrm{~kg}$ ha ${ }^{-1}$ for forage pea, $250 \mathrm{~kg} \mathrm{ha}^{-1}$ for faba bean (cv. Snowbird), $95 \mathrm{~kg} \mathrm{ha}^{-1}$ for vetch (cv. AC Greenfix), and $80 \mathrm{~kg} \mathrm{ha}^{-1}$ for the barley (cv. Metcalf) control. All plots were side-banded with mono-ammonium phosphate (11-22-0 N-P-K) at $22 \mathrm{~kg} \mathrm{P} \mathrm{ha}^{-1}$ at seeding. Soil test recommendations did not include K. No extra $\mathrm{N}$ was applied to any crop. Pea and vetch plants were inoculated with Soil Implant ${ }^{\circledR}$ granular inoculant (Rhizobium leguminosarum bv. viceae) at $5 \mathrm{~kg} \mathrm{ha}^{-1}$. Faba bean was not inoculated because uninoculated plants in these soils nodulate as much, and as effectively (with indigenous rhizobia), as inoculated plants (Lopetinsky et al. 2014). The herbicide 2,4-D amine $500^{\circ}$ (2,4-dichlorophenoxyacetic acid) was applied to barley at $560 \mathrm{~g}$ active ingredient (ai) ha ${ }^{-1}$ on 25 June.

\section{Harvesting Legumes and Barley in 2007}

Growth of GM crops was terminated by cutting at full bloom on 24 July and residues were spread on the soil surface. However, the GM plants regenerated after the first cut and a second cut was done on 18 September. Similarly, residues of crops grown for seed were spread on the surface at the time of grain harvest, i.e., on 12 September for pea and 27 September for faba bean. In Treatments 3 and 4 (Table 1), aboveground residues were removed to leave only stubble in the plots. Barley was harvested on 10 September and the residues were returned. In all crops, yield was determined from $1.38 \mathrm{~m}^{2}$ swaths (6 rows $\times 1 \mathrm{~m}$ ).

\section{Growing Subsequent Crops in 2008-2010}

Before seeding wheat, canola and barley in 2008, 2009 and 2010, respectively, the plots were cleaned of weeds by spraying glyphosate at $450 \mathrm{~g}$ acid equivalent (ae) ha ${ }^{-1}$. In 2008 , the glyphosate burn-off was 
done on 15 May, and wheat (var. Teal) was seeded on 18 May at a seeding rate of $80 \mathrm{~kg} \mathrm{ha}^{-1}$ in rows 23 cm apart. In 2009, glyphosate was applied on 5 May, and Clearfield ${ }^{\mathrm{TM}}$ canola (var. 45P70) was seeded on 15 May at a seeding rate of $7 \mathrm{~kg} \mathrm{ha}^{-1}$. In 2010, the burn-off was done on 14 May before hulless barley (var. Metcalf) was seeded on 15 May at a seeding rate of $90 \mathrm{~kg} \mathrm{ha}^{-1}$. Row spacing was $23 \mathrm{~cm}$ for all crops. All plots were side-banded with 11-22-0 (N-P-K) at $22 \mathrm{~kg} \mathrm{P} \mathrm{ha}^{-1}$ at seeding. The in-crop herbicides applied were florasulum $+2,4-\mathrm{D}$ ester tank mix at $5 \mathrm{~g}$ and $564 \mathrm{~g}$ ae ha ${ }^{-1}$, respectively, to wheat on 12 June 2008, imazamox to canola at $20 \mathrm{~g}_{\text {ae ha }}{ }^{-1}$ on 12 June, 2009, and prodiamine to barley on 10 June, 2010. Wheat and canola were combine-harvested on 12 September, 2008 and 21-23 September, 2009, respectively. Barley yield in 2010 was determined from $0.92 \mathrm{~m}^{2}$ swaths (4 rows $\times 1 \mathrm{~m}$ ) on 23 August.

\section{Soil sampling for microbiological analysis}

In each subsequent crop, soil samples were collected at the flag leaf stage of wheat (first subsequent crop) and barley (third subsequent crop), and at the flowering stage of canola (second subsequent crop), usually in midsummer (July). Plants were excavated from four random 0.5-m lengths of row. Loose soil was shaken off the roots and the remaining soil that had strongly adhered to the roots was carefully brushed off and kept as rhizosphere soil. Bulk soil (0-7.5 cm depth) was sampled from the middle of two adjacent crop rows at four locations per plot. The four bulk or rhizosphere soil samples from each plot were combined, passed through a $2-\mathrm{mm}$ sieve and frozen at $-20{ }^{\circ} \mathrm{C}$ until analysis. Bulk soil samples were also taken after crop harvest in the fall (September in 2008 and 2010, and October in 2009).

\section{Microbial biomass C (MBC)}

Soil MBC was measured using the substrate-induced respiration method (Horwath and Paul 1994), in which $300 \mathrm{mg}$ of glucose was dissolved in 4.5 to $6.0 \mathrm{~mL}$ water and added to $50 \mathrm{~g}$ soil to bring it to $50 \%$ water-holding capacity. The exact amount of water added depended on the pre-determined water 
content and water-holding capacity of the soil. After stir-mixing, the soil was incubated in a $1 \mathrm{~L}$ jar for $3 \mathrm{~h}$ at $22{ }^{\circ} \mathrm{C}$ and the amount of $\mathrm{CO}_{2}$ that accumulated in the head space was measured using gas chromatography.

\section{$\beta$-glucosidase enzyme activity}

The activity of $\beta$-glucosidase enzyme, a key enzyme in C cycling because it is involved in the hydrolysis and biodegradation of cellulose, was measured by colorimetrically determining $p$-nitrophenol released by the enzyme after incubating $1 \mathrm{~g}$ soil with buffered $(\mathrm{pH}$ 6.0) $p$-nitrophenyl- $\beta$-D-glucoside (Dick et al. 1996).

\section{Bacterial physiological diversity and profiles}

Community level physiological profiles (CLPPs) of soil bacteria were evaluated using the Biolog method (Zak et al. 1994), which tests the ability of a bacterial community to utilize different C substrates contained in a microplate (Eco-plate ${ }^{\circ}$ ) (Biolog Inc., Hayward, California). The procedure was adapted by colorimetrically standardizing inoculum densities in $1 \mathrm{~g}$ soil samples to about $10^{3}$ cells $\mathrm{mL}^{-1}$. Aliquots of $150 \mu \mathrm{L}$ of the soil suspension were added to Biolog Ecoplate ${ }^{\oplus}$ microplates containing 31 substrates and a water control (Insam 1997). The plates were incubated at $28^{\circ} \mathrm{C}$ without shaking. Optical densities in the wells were read with an enzyme-linked immunosorbent assay (ELISA) plate reader at $590 \mathrm{~nm}$ after $48 \mathrm{~h}$ of incubation. Preliminary tests showed that treatment differences in substrate utilization profiles read every $12 \mathrm{~h}$ up to $96 \mathrm{~h}$ of incubation were similar throughout the incubation period, but were clearest at $48 \mathrm{~h}$. The optical density readings were corrected for the water controls in subsequent analyses, and negative readings after the correction were adjusted to zero. 
On the basis of CLPPs, physiological diversity was evaluated by calculating the Shannon index (H') following as described by Zak et al. (1994), using Multi-Variate Statistical Package (MVSP) software (Kovach 1999):-

$H^{\prime}=-\Sigma p_{i}\left(\ln p_{i}\right)$

where $\mathrm{p}_{\mathrm{i}}=$ the ratio of activity (i.e., optical density reading) on the $i$ th substrate to the sum of activities on all 31 substrates.

To compare the physiological structures of soil bacterial communities, principal component analysis (PCA) was used to classify treatments according to their CLPPs (Pielou 1984) using MVSP software (Kovach 1999). A covariance matrix of the substrate utilization data was used in the PCA analysis and, after classification, the $\mathrm{C}$ substrates that accounted for differences between classes of treatments in substrate utilization were identified by correlating principal component scores with optical density readings for individual substrates. The most discriminating of these substrates are shown in the PCA plots (Fig. 1) to avoid crowding of the graphs if all the substrates were shown as biplots.

\section{Statistical Analysis}

Each year, statistical analysis of $\mathrm{MBC}, \beta$-glucosidase activity, and $\mathrm{H}^{\prime}$ data in crop rhizosphere or bulk soil was done in two parts. The first part involved determining the effects of different crop residues, and the second part involved evaluating the effect of removing aboveground residues. To evaluate the effects of different crop residues, the analysis included only treatments in which aboveground residues were returned (Treatments 1, 2, 5-8, Table 1). For rhizosphere data, which were collected once each year, analysis of variance (ANOVA) was done according to the RCBD of the trial. For bulk soil data, which were 
collected in summer and in fall, ANOVA using Repeated Measures in RCBD was conducted, with time of sampling as a repeated measure. When significant crop residue effects were observed at $5 \%$ significance level, means were separated by the least significant difference (LSD) method. Singledegree-of freedom contrast analyses were also conducted to compare (a) legumes with barley, (b) pulse crops with GM crops, (c) forage pea with green pea, and (d) faba bean with faba GM, in the measured characteristics. To determine the effects of removing aboveground residues, only treatments 1 to 4 (Table 1), in which pea residues were either returned or removed, were used in ANOVA in a 2 (pea types) $\times 2$ (residue removed or returned) split-plot arrangement of treatments for rhizosphere data, and $2 \times 2 \times 2$ (sampling times) split-split-plot design for bulk soil data. At each sampling time, MBC, $\beta$ glucosidase activity, and $\mathrm{H}^{\prime}$ were related to previously published (a) crop residue $\mathrm{C}$ concentrations, $\mathrm{N}$ concentrations and C:N ratios (Lupwayi et al., 2015), (b) the proportions and release rates of C and $\mathrm{N}$ that had been released relatively quickly from decomposing crop residues (Lupwayi et al. 2015), and (c) subsequent crop N uptake and grain yields (Lupwayi and Soon 2016), through correlation analysis of data from individual replicates. The $\mathrm{N}$ uptake and crop yield data used in (c) were for the $0 \mathrm{~kg} \mathrm{~N} \mathrm{ha}^{-1} \mathrm{~N}$ rate because soil microbial characteristics were determined at that $\mathrm{N}$ rate only.

\section{RESULTS}

\section{Growing Season Rainfall and Temperature}

Precipitation during the growing season (May to September) in 2007 was normal (99\% of 30-year mean of $271 \mathrm{~mm}$ ) even though July received only $52 \%$ of normal precipitation (Table 2). However, precipitation in each of the three subsequent seasons was below normal, critically so in June and July of 2008 and 2010, and June and August of 2009, and the crops suffered moisture deficits during those periods. Mean air temperature was mostly normal in all seasons although July and August of 2007 had temperatures $10 \%$ higher and $16 \%$ lower than normal, respectively. 


\section{Soil Microbial Biomass}

There were significant effects of crop residues on $M B C$ in wheat rhizosphere (Table 3), where the order of $\mathrm{MBC}$ was: Faba $\mathrm{GM} \geq$ Forage pea $\geq$ Faba bean $\geq$ Barley $\geq$ Vetch $\mathrm{GM}=$ Green pea (Table 4). Contrast analysis confirmed the difference between forage pea and green pea in their effects on MBC. In bulk soil, contrast analysis revealed greater MBC in GM residues than in residues of pulse crops (Table 4). Sampling time (summer vs. fall) had no effect on MBC in bulk soil. Removal of aboveground pea residues did not affect $\mathrm{MBC}$ (Tables 3).

In canola, there were no overall residue effects on $\mathrm{MBC}$ in the rhizosphere or bulk soil when all crop residues were compared (Table 3). Sampling time affected MBC in bulk soil, with greater MBC in summer than in fall (Table 4). However, when only pea residues were compared in residue-removal effects (Table 3), MBC in canola rhizosphere was greater under green pea residues ( $805 \mathrm{mg} \mathrm{kg}^{-1}$ soil) than under forage pea residues $\left(680 \mathrm{mg} \mathrm{kg}^{-1}\right.$ soil). The removal of pea residues did not affect MBC.

There were no significant effects of crop residues on MBC in barley rhizosphere (Table 3). When all crop residues were compared in bulk soil, the residues of vetch GM, faba GM and faba bean resulted in greater soil MBC than the other residues (Table 4). Contrast analysis confirmed that legume residues resulted in greater soil $\mathrm{MBC}$ than barley residues, but also that $\mathrm{GM}$ residues resulted in greater soil MBC than residues of pulse crops. When only pea residues were compared in residue removal effects, there was interaction between pea residues and residue removal in $\mathrm{MBC}$ (Table 3). Thus, the removal of green pea residues reduced MBC from 931 to $791 \mathrm{mg} \mathrm{kg}^{-1}$ soil (the corresponding values for forage pea were $846 \mathrm{mg} \mathrm{kg}^{-1}$ soil where residues had been retained and $899 \mathrm{mg} \mathrm{kg}^{-1}$ soil where residues had been removed). Sampling time had no effect on MBC in bulk soil.

\section{$\beta$-glucosidase enzyme activity}


Effects of crop residues and sampling time were observed in bulk soil, but not in wheat rhizosphere (Table 5). In bulk soil, residues of faba bean and faba GM resulted in greater enzyme activities than forage pea, green pea and barley; vetch GM had intermediate activity between the two groups (Table 6). Targeted comparisons by contrast analysis did not reveal any differences in enzyme activities. The enzyme activity was greater in the fall after crop harvest than in summer (Table 6), and removal of pea residues did not affect enzyme activity (Table 5).

Crop residues affected the activity of this enzyme both in canola rhizosphere and bulk soil, where sampling time also affected enzyme activity (Table 5). Residues of faba bean and faba GM resulted in the highest enzyme activities both in canola rhizosphere and bulk soil (Table 6). Whereas residues of forage pea and green pea resulted in the lowest enzyme activities in canola rhizosphere, the lowest activities in bulk soil were under forage pea and barley residues. Contrast analysis revealed greater enzyme activity under residues of faba bean than under faba GM in the rhizosphere (Table 6). The enzyme activity was greater in the fall than in summer (Table 6), but removal of pea residues did not affect enzyme activity (Table 5).

In barley, effects of crop residues and sampling time were observed in bulk soil, but not in the rhizosphere (Table 5). In bulk soil, residues of faba GM, faba bean and vetch GM resulted in greater soil enzyme activities than the other residues (Table 6). Contrast analysis showed that GM residues resulted in greater soil enzyme activity than pulse crop residues. The enzyme activity was greater in fall after barley harvest than in summer. Removal of pea residues reduced $\beta$-glucosidase enzyme activity by $11 \%$

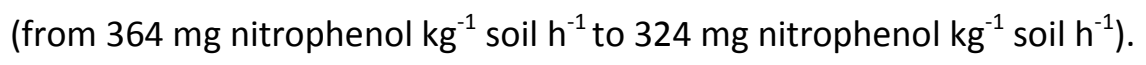

\section{Bacterial physiological diversity}

Crop residues had no effects on the physiological diversity (Shannon index, $\mathrm{H}^{\prime}$ ) of bacteria in wheat rhizosphere. In bulk soil, the effect of crop residues depended on sampling time (Table 7), i.e., whereas 
forage pea and vetch GM residues resulted in greater $\mathrm{H}^{\prime}$ in the fall than summer, the reverse was true for residues of faba bean (interaction results not presented). Forage pea residues resulted in greater soil bacterial diversity than green pea residues, according to contrast analysis (Table 8). Removal of aboveground crop residues did not affect $\mathrm{H}^{\prime}$ (Table 7).

Crop residues had no effects on the physiological diversity of bacterial communities in canola rhizosphere (Table 7). In bulk soil, only sampling time affected bacterial diversity when all residues were compared (Table 7), i.e., $\mathrm{H}^{\prime}$ was greater in fall than in summer (Table 8). There was interaction between pea type and residue removal in bacterial diversity in bulk soil. Thus, the removal of forage pea residues increased $\mathrm{H}^{\prime}$ from 1.62 to 2.28 , whereas the removal of green pea residues decreased $\mathrm{H}^{\prime}$ from 2.19 to 1.81 (log scale). Targeted comparisons showed that bacterial diversity was greater under forage pea residues than under green pea residues (Table 8).

Crop residues had no effects on the physiological diversity of bacterial communities in barley rhizosphere or bulk soil (Table 7). In bulk soil, bacterial diversity was greater in summer than in fall (Table 8). Removal of aboveground crop residues did not affect $\mathrm{H}^{\prime}$.

\section{Physiological structures of bacterial communities}

There were no interpretable differences between crop residue treatments in bacterial community structures in wheat rhizosphere or bulk soil, in summer or fall. In canola, PCA of the data collected after harvest in fall revealed that the structures of bacterial communities in the soil under residues of forage pea, faba bean and faba GM were different from those under residues of barley, green pea and vetch GM (along PC1 in Fig. 1a). The BIOLOG substrates D-galacturonic acid (carboxylic acid), D-xylose (carbohydrate) and glucose-1-phosphate (carbohydrate) were amongst the substrates that were utilized more in the soil under residues of forage pea, faba bean and faba GM than in the soil under residues of barley, green pea and vetch GM. 
In bulk soil at flag leaf growth stage of barley, there were similar differences between crop residue treatments in bacterial community structures to those that had been observed in the preceding fall after canola harvest (described above). Thus, the structures of bacterial communities in the soil under residues of faba GM, faba bean and forage pea were different from those under barley, green pea and vetch GM (along PC1 in Fig. 1b). The BIOLOG substrates $\beta$-methyl-D-glucoside, glucose-1-phosphate and N-acetyl-D-glucosamine, which are all carbohydrates, were amongst the substrates that were utilized more in the soil under residues of faba GM, faba bean and forage pea than in the soil under residues of barley, green pea and vetch GM.

\section{Correlations}

Microbial biomass $\mathrm{C}$ in summer bulk soils under wheat (first subsequent crop) and barley (third subsequent crop) was positively correlated with the $\mathrm{N}$ concentrations of decomposing crop residues $(r=$ $0.542, P=0.014$, and $r=0.561, P=0.010$, respectively). The corresponding correlations for $\beta$ glucosidase activity at the same times in bulk soil were $r=0.560, P=0.010$, and $r=0.612, P=0.004$, respectively. These positive correlations of $\mathrm{MBC}$ and enzyme activity with $\mathrm{N}$ concentrations were mirrored by negative correlations with C: $\mathrm{N}$ ratio at the same times in bulk soil. For example, Fig. 2 shows the negative regression between MBC in summer bulk soil under barley and C:N ratio $(r=-0.629$, $\mathrm{P}=0.003$ ). Microbial biomass $\mathrm{C}$ in wheat rhizosphere in summer, $\mathrm{MBC}$ in canola bulk soil after canola harvest in the fall, and $\beta$-glucosidase enzyme activity of the same, were all negatively correlated with residue $C$ concentrations ( $r \approx-0.51, P \approx 0.02$ in all three cases). Significant correlations between soil microbial characteristics and $\mathrm{C}$ and $\mathrm{N}$ release from the decomposing crop residues showed that $\mathrm{MBC}$ under wheat and barley was mostly positively correlated with the proportion of crop residue C that had been released quickly, $\beta$-glucosidase enzyme activities under wheat and barley were mostly positively 
correlated with the rates of release of $\mathrm{C}$ and $\mathrm{N}$, and $\mathrm{H}^{\prime}$ under wheat was mostly positively related with the rate of release of $\mathrm{C}$ (data not shown).

The only significant correlation between soil microbial properties and crop N uptake or grain yield at $0 \mathrm{~kg} \mathrm{~N} \mathrm{ha}^{-1}$ was a negative correlation between $\beta$-glucosidase enzyme activity in wheat rhizosphere in summer and wheat $\mathrm{N}$ uptake $(r=-0.464, \mathrm{P}=0.022)$, and the regression is shown in Fig. 3. However, close inspection of the data points in that figure shows greater variation between the four replicates of each treatment than between the treatments themselves. In any case, the low coefficient of determination (adjusted $R^{2}=0.180$ ) suggests that it was a weak relationship.

\section{DISCUSSION}

Almost all differences between crop residues in their effects on soil MBC and $\beta$-glucosidase enzyme activity were due to faba GM or faba bean increasing these microbial properties relative to the other residues in soil under wheat, canola or barley (Tables 4 and 6). This faba bean effect was probably a result of increased soil $\mathrm{N}$, either directly as a nutrient for soil microbes, or indirectly by increasing the root growth and activity (rhizodeposition) of subsequent crops. Faba bean fixed the most $\mathrm{N}_{2}(184 \mathrm{~kg} \mathrm{~N}$ $\left.\mathrm{ha}^{-1}\right)$ and also released the most $\mathrm{N}\left(135 \mathrm{~kg} \mathrm{~N} \mathrm{ha}^{-1}\right)$ to the soil during residue decomposition (Lupwayi and Soon 2015). Although faba $\mathrm{GM}$ fixed less $\mathrm{N}\left(77 \mathrm{~kg} \mathrm{~N} \mathrm{ha}^{-1}\right)$ than faba bean, it released substantial amounts of $\mathrm{N}\left(97 \mathrm{~kg} \mathrm{~N} \mathrm{ha}^{-1}\right.$ ) to the soil due to its low C:N ratio (Lupwayi and Soon 2015). The $\mathrm{N}$ effect is corroborated by the fact that, relative to the barley control, vetch $\mathrm{GM}$ also increased MBC and $\beta$ glucosidase enzyme activity in the third subsequent crop (Tables 4 and 6). Residues of vetch GM released more $\mathrm{N}\left(128 \mathrm{~kg} \mathrm{~N} \mathrm{ha}^{-1}\right)$ than green pea residues (60 kg N ha ${ }^{-1}$ ) (Lupwayi and Soon 2015). Crop residue effects on the physiological diversity of soil bacteria were mixed, but the bacterial community structures in the soils under faba bean and faba GM (and also forage pea) residues were different from those of soils under the other residues (Figs. 1a, b). Other workers have not found differences between 
faba bean and other legumes in their effects on soil microbial properties in subsequent crops (Mayer et al. 2003; Alamgir and Marschner 2013; St Luce et al. 2013). At five sites in the Canadian prairies, St Luce et al. (2013) found no differences in soil microbial biomass $\mathrm{N}$ under canola crops that had been grown after faba bean, faba GM, pea, canola or wheat. Similarly, in three soils amended with residues of faba bean, chickpea (Cicer arietnum L.) and white lupin (Lupinis albus L) in an incubation study, Alamgir and Marschner (2013) found no differences in soil microbial biomass P. However, changes in soil microbial properties are observed when faba bean is compared with nonlegume crops such as barley (Wani et al. 1994; Chang and Juma 1996). Faba bean is known for its high $\mathrm{N}_{2}$-fixing capability (Jensen et al. 2010), and some of the ecological services that it provides as a result of that capability have been documented (Kopke and Nemecek 2010).

It is surprising that $\mathrm{GM}$ crop residues increased soil $\mathrm{MBC}$ and $\beta$-glucosidase enzyme activity more than pulse crop residues even in the third subsequent crop (Tables 4 and 6 ). The $\mathrm{N}$ release profiles of aboveground residues of these legumes showed that GM residues released most of their $N$ in the first year of decomposition and very little thereafter, whereas pea residues released little $\mathrm{N}$ in the first year and more $\mathrm{N}$ in the second and third years (Lupwayi and Soon 2015). Crop N uptake, C accumulation and grain yield data also showed waning rotational effects of GM residues with time, and the effects of pulse crop residues on these crop responses were greater than GM residue effects in the third crop (Lupwayi and Soon 2016). This discrepancy could be a result of belowground contributions of C and N (discussed below).

When there were differences, soil microbial properties were greater under forage pea residues than under green pea residues. This difference was expected because of biomass differences between the two pea types. The green pea variety was semi-leafless and the forage pea variety was normalleafed. Semi-leafless peas are currently the preferred type for grain production because they are resistant to lodging, but leafed varieties are still preferred for biomass used for forage or GM (Syrovy et 
al. 2015). The amounts of $\mathrm{N}_{2}$ fixed, aboveground biomass, and the $\mathrm{N}$ contained and released by the residues during decomposition, were all greater in forage pea than in green pea (Lupwayi et al. 2015).

Most soil microorganisms depend on organic $\mathrm{C}$ for cell growth and energy. Returning crop residues to the soil is one way of maintaining or increasing soil organic $\mathrm{C}$ because plant litter is the main source of soil C (Blanco-Canqui and Lal 2009). Therefore, removal of aboveground crop residues is expected to adversely affect soil microbial communities, unless other sources of $C$ can be accessed. In this study, the removal of aboveground pea residues had inconsistent effects on soil microbial properties. There were no effects in the first subsequent crop. Forage pea removal increased bacterial physiological diversity in the second subsequent crop (Table 7). In the third subsequent crop, removal of green pea residues reduced $\mathrm{MBC}$ (interaction effect shown in Table 3), and removal of both pea residues reduced $\beta$-glucosidase enzyme activity (Table 5). Soon and Lupwayi (2012) also reported inconsistent crop residue removal effects on $\mathrm{MBC}$ and $\beta$-glucosidase enzyme activities in the same study area. Negative aboveground residue removal effects on soil microbial properties have been reported in some studies (Graham et al. 2002; Soon and Arshad 2004; Powlson et al. 2011) but not in others (Soon 1998; Powlson et al. 2011). These effects depend on many factors, including amounts of residues removed, the duration of residue removal, and local soil and environmental factors. In the current study, the removal of aboveground residues had no effects on $\mathrm{N}$ uptake, $\mathrm{C}$ accumulation and grain and straw yields of all three subsequent crops (Lupwayi and Soon 2016). These results show that belowground sources (decomposing plant roots and rhizodeposits) also contributed to the soil $\mathrm{C}$ and $\mathrm{N}$ pools that affected soil microbial properties and subsequent crop growth. Arcand et al. (2014), in a greenhouse study using ${ }^{15} \mathrm{~N}$ labeling of pea and canola residues, showed that wheat grown on these residues derived twice as much $\mathrm{N}$ from belowground residues as from aboveground residues. Soon and Arshad (2004) reported that belowground $\mathrm{N}$ from pea contributed $13-23 \%$ of the $\mathrm{N}$ accumulated by the sequent barley crop compared with a 1-3\% contribution from pea straw residues. It is possible that the subsequent crops 
themselves confounded the effects of the legume residues. However, because we did not have each phase of the rotations grown every year, we could not evaluate the effects of the subsequent crops themselves.

Summer and fall sampling times had opposite effects on bacterial physiological diversity in canola and barley (Table 8). Whereas the only effect of sampling time on MBC was in canola, where $M B C$ was greater in summer than in the fall (Table 4), $\beta$-glucosidase activity was always greater in the fall than in summer (Table 6). Temperatures in September to October, when the soils were sampled in the fall, are normally at least $5{ }^{\circ} \mathrm{C}$ lower than in July (Table 2), suggesting that the increase in enzyme activity was not due to soil temperature. The soil in the fall was sampled just after crop harvest, and the high $\beta$-glucosidase enzyme activity was probably a response to new sources of soil labile organic $C$ through addition of fresh crop residues. Hoyle and Murphy (2006) also reported seasonal differences, related to soil $\mathrm{C}$ availability, in $\beta$-glucosidase enzyme activity in western Australia although their sampling regime did not include sampling after crop harvest. However, Bandick and Dick (1999) found that the activity of this enzyme was fairly stable throughout the season in Oregon, USA. Therefore, $\beta$ glucosidase activity was a better indicator of crop residue effects than MBC or physiological bacterial diversity because it was the most sensitive (Table 5) and consistent (Table 6) indicator, and it was negatively affected by residue removal in barley (Table 5).

The $\mathrm{N}$ concentration of the crop residues was an important factor in soil $\mathrm{MBC}$ and $\beta$-glucosidase enzyme activity because these two factors were usually positively correlated with residue $\mathrm{N}$ concentration and negatively correlated with C:N ratio or C concentration. Interestingly, whereas soil MBC was associated with the degree of $C$ release (the proportion of crop residue $C$ that was released quickly), $\beta$-glucosidase enzyme activity and physiological diversity were associated with the rates of $\mathrm{C}$ or $\mathrm{N}$ release from crop residues. The correlation between soil $\mathrm{MBC}$ and the degree of $\mathrm{C}$ release links back to $\mathrm{N}$ concentration because previously-published results from the same study showed that the 
proportion of quickly-released $\mathrm{C}$ in the crop residues was positively correlated with their initial $\mathrm{N}$ concentrations and negatively correlated with their C: $\mathrm{N}$ ratios (Lupwayi and Soon 2015). The significance of $\mathrm{N}$ concentration was also observed for DM decomposition in red clover (Trifolium pratense L.) GM, pea, canola (B. rapa L.) and wheat residues in the same study area (Lupwayi et al. 2004).

There was a weak negative correlation between $\beta$-glucosidase enzyme activity in wheat rhizosphere in summer and wheat $\mathrm{N}$ uptake at $0 \mathrm{~kg} \mathrm{~N} \mathrm{ha}^{-1}$. This was a surprising result considering that neither wheat $\mathrm{N}$ uptake nor grain yield correlated with the percentage of quickly-released $\mathrm{N}$ contained in the residues, or the rate of release of that $\mathrm{N}$ (Lupwayi et al. 2016). The only correlation that was close to being significant $(r=0.854, P=0.066)$ was between wheat grain yield and the rate of release of quickly-released N (Lupwayi et al. 2016). The data points showing greater within-replicate variation than between-treatment variation (Fig. 3) explain why this was a surprising result.

\section{SUMMARY AND CONCLUSIONS}

Decomposing faba GM and faba bean residues almost always resulted in the highest soil MBC and $\beta$ glucosidase enzyme activity relative to the other residues in soil under wheat, canola or barley, presumably due to faba bean's high $\mathrm{N}_{2}$ fixation and/or $\mathrm{N}$ release capability. Green manure crop residues increased bulk soil MBC and $\beta$-glucosidase enzyme activity more than pulse crop residues even in the third subsequent crop, even though aboveground GM residues released most of their $\mathrm{N}$ in the first year of decomposition and very little thereafter. A possible reason was the significant contributions of belowground substrates, as removal of aboveground residues had inconsistent effects on soil microbial properties. Previously published results on crop $\mathrm{N}$ uptake and yield also suggested that belowground residues and rhizodeposition were very important in recycling nutrients. Nonetheless, returning aboveground crop residues to the soil is important as routine removal could eventually reduce soil 
organic C, which improves soil physical, chemical and biological properties. Forage pea sometimes increased soil microbial properties more than green pea, probably due to biomass differences between the full-leafed forage pea and semi-leafless green pea. $\beta$-glucosidase activity was always greater in the fall after crop harvest than in summer, probably due to increased soil substrate through addition of fresh crop residues. The initial $\mathrm{N}$ concentration of the crop residues was an important factor in soil MBC and $\beta$-glucosidase activity because these two factors were often positively correlated with residue $\mathrm{N}$ concentration and negatively correlated with C:N ratio or $\mathrm{C}$ concentration. The physiological diversity of soil bacteria did not respond consistently to the crop residues. Therefore, $\beta$-glucosidase activity was a more sensitive and consistent biological indicator of crop residue effects than $\mathrm{MBC}$ or bacterial physiological diversity. These results are important in biological soil health assessments. However, further microbial characterization using alternative methods like phospholipid fatty acid biomarkers (including stable isotope probing), metagenomics and metatranscriptomics is recommended to further understand soil microbial composition and functioning during crop residue decomposition.

\section{ACKNOWLEDMENTS}

We gratefully acknowledge the assistance of Mandy Collins, Andrea Eastman, Shirley Neighbour and Rahman Azooz in field operations and laboratory analyses. Financial assistance was provided by Alberta Crop Industry Development Fund (ACIDF) and Alberta Pulse Growers (APG).

Alamgir, M. and Marschner, P. 2013. Changes in phosphorus pools in three soils upon addition of legume residues differing in carbon/phosphorus ratio. Soil Res. 51: 484-493.

Araujo, P.I., Yahdjian, L. and Austin, A.T. 2012. Do soil organisms affect aboveground litter decomposition in the semiarid Patagonian steppe, Argentina? Oecologia 168: 221-230. 
Arcand, M.M., Knight, J.D. and Farrell, R.E. 2014. Differentiating between the supply of $\mathrm{N}$ to wheat from above and belowground residues of preceding crops of pea and canola. Biol. Fertil. Soils 50: 563-570.

Bandick, A.K. and Dick, R.P. 1999. Field management effects on soil enzyme activities. Soil Biol. Biochem. 31: 1471-1479.

Blanco-Canqui, H. and Lal, R. 2009. Crop residue removal impacts on soil productivity and environmental quality. Crit. Rev. Plant Sci. 28: 139-163.

Chang, X.C. and Juma, N.G. 1996. Impact of crop rotations on microbial biomass, faunal populations, and plant $\mathrm{C}$ and $\mathrm{N}$ in a gray luvisol (Typic Cryoboralf). Biol. Fertil. Soils 22: 31-39.

Deng, S.P. and Tabatabai, M.A. 1996. Effect of tillage and residue management on enzyme activities in soils. II. Glycosidases. Biol. Fertil. Soils 22: 208-213.

Dick, R.P., Breakwell, D.P. and Turco, R.F. 1996. Soil enzyme activities and biodiversity measurements as integrative microbiological indicators. In: Doran, J.W., Jones, A.J. (Eds.), Methods for Assessing Soil Quality. SSSA Special Publication Number 49. Soil Sci. Soc. Am. Inc., Madison, WI, pp. 247-271.

Doran, J.W. and Safley, M. 1997. Defining and assessing soil health and sustainable productivity. In: Pankhust, C.E., Doube, B.M. and Gupta, V.V.S.R. (Eds.), Biological Indicators of Soil Health. CAB International, Wallingford, UK, pp. 1-28.

Graham, M.H., Haynes, R.J. and Meyer, J.H. 2002. Soil organic matter content and quality: effects of fertilizer applications, burning and trash retention on a long-term sugarcane experiment in South Africa. Soil Biol. Biochem. 34: 93-102.

Horwath, W.R. and Paul, E.A. 1994. Microbial biomass. In: R.W. Weaver, S. Angle, P. Bottomly, D. Bezdicek, S. Smith, A. Tabatabai, and A. Wollum, Editors, Methods of soil analysis. Part 2. Microbiological and biochemical properties. Soil Sci. Soc. Am., Madison, WI. p. 753-773. 
Hoyle, F.C. and Murphy, D.V. 2006. Seasonal changes in microbial function and diversity associated with stubble retention versus burning. Aust. J. Soil Res. 44: 407-423.

Insam, H. 1997. A new set of substrates proposed for community characterization in environmental samples. In: H. Insam, and A. Rangger, Editors, Microbial communities: functional versus structural approaches. Springer, Berlin, pp. 260-261.

Kovach, W.L. 1999. MVSP - A multivariate statistical package for Windows, Ver. 3.1. Kovach Computing Services, Pentraeth, Wales, UK. 137 pp.

Jensen, E.S., Peoples, M.B. and Hauggard-Nielsen, H. 2010. Faba bean in cropping systems. Field Crops Res. 115: 203-216.

Kopke, U. and Nemecek, T. 2010. Ecological services of faba bean. Field Crops Res. 115: 217-233. Lopetinsky, K.J., Lupwayi, N.Z., Olson, M.A., Akter, Z. and Clayton, G.W. 2014. Contrasting Rhizobium inoculation requirements of zero-tannin faba bean and narrow-leafed lupin in western Canada. Can. J. Plant Sci. 94: 1117-1123.

Lupwayi, N.Z. and Soon, Y.K. 2015. Carbon and nitrogen release from legume crop residues over three subsequent crops. Soil Sci. Soc. Am. J. 79: 1650-1659.

Lupwayi, N.Z. and Soon, Y.K. 2016. Nitrogen-related rotational effects of legume crops on three consecutive subsequent crops. Soil Sci. Soc. Am. J. 80: 306-316.

Lupwayi, N.Z., Clayton, G.W., O’Donovan, J.T., Harker, K.N., Turkington, T.K. and Rice, W.A. 2004. Soil microbiological properties during decomposition of crop residues under conventional and zero tillage. Can. J. Soil Sci. 84: 411-419.

Mayer, J., Buegger, F., Jensen, E.S., Schloter, M. and Hess, J. 2003. Residual nitrogen contribution from grain legumes to succeeding wheat and rape and related microbial process. Biol. Fertil. Soils 255: 541-554. 
Moreno-Cornejo, J., Zornoza, R., Faz, A. and Rosales, R.M. 2013. Effects of pepper crop residues and inorganic fertilizers on soil properties relevant to carbon cycling and broccoli production. Soil Use Manage. 29: 519-530.

Partey, S.T., Preziosi, R.F. and Robson, G.D. 2014. Improving maize residue use in fertility restoration by mixing with residues of low $\mathrm{C}$-to- $\mathrm{N}$ ratio: effects on $\mathrm{C}$ and $\mathrm{N}$ mineralization and soil microbial biomass. J. Soil Sci. Plant Nutr. 14: 518-531.

Pascault, N., Cécillon, L., Mathieu, O., Hénault, C., Sarr, A., Lévêque, J., Farcy, P., Ranjard, L. and Maron, P. 2010. In situ dynamics of microbial communities during decomposition of wheat, rape, and alfalfa residues. Soil Ecol. 60: 816-828.

Pielou, E.C. 1984. The interpretation of ecological data: a primer on classification and ordination. John Wiley \& Sons, New York, NY. 263 pp.

Powlson, D.S., Gledining, M.J., Coleman, K. and Whitmore, A.P. 2011. Implication for soil properties of removing cereal straw: results from long-term studies. Agron. J. 103: 279-287.

Saskatchewan Pulse Growers, 2011. Pea production manual, 2011/2012. Saskatchewan Pulse Growers, Saskatoon, SK, 60 pp. (www.saskpulse.com/uploads/.../111207 FINAL Pea Manual.pdf) accessed May 20, 2015.)

Soon, Y.K. 1998. Crop residue and fertilizer management effects on some biological and chemical properties of a Dark Grey Solod. Can. J. Soil Sci. 78: 707-713.

Soon, Y.K. and Arshad, M.A. 2004. Tillage, crop residue and crop sequence effects on nitrogen availability in a legume-based cropping system. Can. J. Soil Sci. 84: 421-430.

Soon, Y.K. and Lupwayi, N.Z. 2012. Straw management in a cold semi-arid region: impact on soil quality and crop productivity. Field Crops Res. 139: 39-46.

Statistics Canada. 2014. Pulses in Canada. Statistics Canada - Catalogue no. 96-325-X. Ottawa, ON, 10 pp. 
St. Luce, M., Ziadi, N., Zebarth, B.J., Whalen, J.K., Grant, C.A., Gregorich, E.G., Lafond, G.P., Blackshaw, R.E., Johnson, E.N., O'Donovan, J.T. and Harker, K.N. 2013. Particulate organic matter and soil mineral nitrogen concentrations are good predictors of the soil nitrogen supply to canola following legume and non-legume crops in western Canada. Can J. Soil Sci. 93: 607-620.

Syrovy, L.D., Banniza, S. and Shirtliffe, S.J. 2015. Yield and agronomic advantages of pea leaf type mixtures under organic management. Agron. J. 107: 113-120.

Wani, S.P., McGill, W.B., Haugen-Kozyra, K.L., Robertson, J.A. and Thurston, J.J. 1994. Improved soil quality and barley yields with faba beans, manure, forages and crop rotation on a Gray Luvisol. Canadian Journal of Soil Science 74: 75-84.

Zak, J.C., Willig, M.R., Moorhead, D.L. and Wildman, H.G. 1994. Functional diversity of microbial communities: A quantitative approach. Soil Biol. Biochem. 26: 1101-1108. 
Table 1. Treatments from 2007 to 2010. The legumes (and barley control) were grown in 2007, wheat in 2008, canola in 2009, and barley in 2010. No extra $\mathrm{N}$ (other than the little $\mathrm{N}$ applied with P fertilizer) was added to any crop. Unless stated otherwise, aboveground crop residues were returned to the soil

\begin{tabular}{ll} 
Treatment & Crop rotation \\
\hline 1 & Forage pea-Wheat-Canola-Barley \\
2 & Green pea-Wheat-Canola-Barley \\
3 & Forage pea (residues removed)-Wheat-Canola-Barley \\
4 & Green pea (residues removed)-Wheat-Canola-Barley \\
5 & Faba bean ${ }^{\mathrm{a}}$-Wheat-Canola-Barley \\
6 & Faba green manure (GM) ${ }^{\mathrm{b}}$-Wheat-Canola-Barley \\
7 & Vetch GM-Wheat-Canola-Barley \\
8 & Barley (Control)-Wheat-Canola-Barley \\
\hline${ }^{\mathrm{a} F a b a}$ bean = Faba bean grown for seed, harvested at seed maturity. \\
${ }^{\mathrm{b}}$ Faba GM = Faba bean grown for green manure, terminated at flowering time.
\end{tabular}


Table 2. Growth period (May to September) precipitation and air temperature (\% of 30-yr mean) from 2007 to 2010

\begin{tabular}{|c|c|c|c|c|c|}
\hline Month & 2007 & 2008 & 2009 & 2010 & $\begin{array}{c}\text { 30-yr mean ( } \mathrm{mm} \\
\left.\text { or }^{\circ} \mathrm{C}\right)^{\mathrm{a}}\end{array}$ \\
\hline \multicolumn{6}{|l|}{ Rainfall } \\
\hline May & 190 & 93 & 107 & 169 & 37.5 \\
\hline June & 77 & 30 & 21 & 29 & 63.6 \\
\hline July & 52 & 28 & 175 & 39 & 72.2 \\
\hline August & 131 & 128 & 36 & 94 & 57.9 \\
\hline September & 85 & 127 & 70 & 58 & 39.3 \\
\hline Total & 99 & 73 & 84 & 69 & 270.5 \\
\hline \multicolumn{6}{|c|}{ Mean air temperature } \\
\hline May & 94 & 107 & 82 & 79 & 9.6 \\
\hline June & 101 & 97 & 96 & 99 & 13.6 \\
\hline July & 110 & 101 & 101 & 103 & 15.7 \\
\hline August & 86 & 104 & 104 & 99 & 14.6 \\
\hline September & 94 & 106 & 106 & 85 & 10.0 \\
\hline Mean & 96 & 102 & 102 & 94 & 12.7 \\
\hline
\end{tabular}

${ }^{\mathrm{a}} 30$ years $=1981$ to 2010 . 
Table 3. Analysis of variance summary of legume residue effects on microbial biomass $C(M B C)$ during wheat (2008), canola (2009) and barley (2010) crops grown after legumes (2007)

\begin{tabular}{|c|c|c|c|c|c|c|}
\hline \multirow[t]{3}{*}{ Effect } & \multicolumn{2}{|c|}{ Wheat } & \multicolumn{2}{|c|}{ Canola } & \multicolumn{2}{|c|}{ Barley } \\
\hline & Rhizo $^{a}$ & Bulk soil & Rhizo & Bulk soil & Rhizo & Bulk soil \\
\hline & \multicolumn{6}{|c|}{$P$ values } \\
\hline \multicolumn{7}{|c|}{ Crop residue effects (all treatments in which aboveground residues were returned) } \\
\hline Crop residue $(C)\left(15,18 \mathrm{df}^{\mathrm{b}}\right)$ & 0.013 & 0.217 & 0.093 & 0.362 & 0.859 & $<0.001$ \\
\hline Sampling time $(T)$ (18 df) & $N A^{c}$ & 0.087 & NA & $<0.001$ & NA & 0.390 \\
\hline $\mathrm{C} \times \mathrm{T}(18 \mathrm{df})$ & NA & 0.802 & NA & 0.770 & NA & 0.541 \\
\hline \multicolumn{7}{|c|}{ Aboveground pea residue removal effects (Treatments 1-4) } \\
\hline Pea type $(P)$ (3 df) & 0.385 & 0.920 & 0.014 & 0.463 & 0.081 & 0.898 \\
\hline Residue removal (R) (6 df) & 0.495 & 0.475 & 0.245 & 0.657 & 0.064 & 0.278 \\
\hline$P \times R(6 d f)$ & 0.333 & 0.916 & 0.236 & 0.115 & 0.178 & 0.037 \\
\hline $\mathrm{T}(12 \mathrm{df})$ & NA & 0.204 & NA & 0.003 & NA & 0.488 \\
\hline$P \times T(12 d f)$ & NA & 0.765 & NA & 0.556 & NA & 0.608 \\
\hline$R \times T(12 d f)$ & NA & 0.663 & NA & 0.643 & NA & 0.355 \\
\hline$P \times R \times T(12 d f)$ & NA & 0.673 & NA & 0.802 & NA & 0.852 \\
\hline
\end{tabular}

${ }^{\mathrm{a}}$ Rhizo $=$ rhizosphere.

${ }^{b} d f=$ degrees of freedom for error. Where there are two numbers, the first one is for rhizosphere data, and the second one for bulk soil data.

${ }^{\mathrm{c}} \mathrm{NA}=$ not applicable because rhizosphere samples were not collected in the fall after crop harvest. 
Table 4. Microbial biomass C (MBC) during wheat (2008), canola (2009) and barley (2010) crops grown after legumes (2007) in the treatments where residues were returned

\begin{tabular}{|c|c|c|c|c|c|c|}
\hline \multirow[t]{3}{*}{ Treatment } & \multicolumn{2}{|c|}{ Wheat } & \multicolumn{2}{|c|}{ Canola } & \multicolumn{2}{|c|}{ Barley } \\
\hline & Rhizo $^{\mathrm{a}}$ & Bulk soil & Rhizo & Bulk soil & Rhizo & Bulk soil \\
\hline & \multicolumn{6}{|c|}{ MBC (mg kg ${ }^{-1}$ soil) } \\
\hline \multicolumn{7}{|l|}{ Crop residues } \\
\hline Forage pea & $509 a b$ & $605 a$ & $681 a$ & $648 a$ & $972 a$ & $899 b$ \\
\hline Green pea & $371 c$ & $600 a$ & $720 a$ & $665 a$ & $850 a$ & $791 b$ \\
\hline Faba bean & $488 a b c$ & $644 a$ & $923 a$ & $815 a$ & $990 a$ & $1045 a$ \\
\hline Faba $\mathrm{GM}^{\mathrm{b}}$ & $580 a$ & $806 a$ & $822 a$ & $803 a$ & $1003 a$ & $1055 a$ \\
\hline Vetch GM & $385 c$ & $675 a$ & $747 a$ & $683 a$ & $910 a$ & $1065 a$ \\
\hline Barley & $388 b c$ & $602 a$ & $822 a$ & $697 a$ & $1010 a$ & $846 b$ \\
\hline $\operatorname{SEM}^{c}\left(15,18 d f^{d}\right)$ & 41.2 & 63.9 & 57.3 & 66.6 & 103.4 & 44.3 \\
\hline \multicolumn{7}{|l|}{ Sampling time } \\
\hline Summer & $N A^{e}$ & $692 a$ & NA & $821 a$ & NA & $975 a$ \\
\hline Fall & NA & $619 a$ & NA & $616 b$ & NA & $925 a$ \\
\hline SEM (18 df) & NA & 28.5 & NA & 33.8 & NA & 44.3 \\
\hline \multicolumn{7}{|l|}{ Contrasts } \\
\hline Legumes vs Barley & 0.101 & 0.373 & 0.496 & 0.725 & 0.577 & 0.019 \\
\hline Pulse crops vs GM & 0.496 & 0.046 & 0.861 & 0.587 & 0.840 & 0.002 \\
\hline Forage pea vs Green pea & 0.032 & 0.960 & 0.631 & 0.859 & 0.415 & 0.102 \\
\hline Faba bean vs Faba GM & 0.135 & 0.087 & 0.229 & 0.896 & 0.929 & 0.867 \\
\hline
\end{tabular}

Note: Means followed by the same letter in a column (within a treatment group) are not significantly different at $P=0.05$. 
${ }^{\mathrm{a}}$ Rhizo $=$ rhizosphere.

${ }^{\mathrm{b}} \mathrm{GM}=$ green manure.

${ }^{\mathrm{c}} \mathrm{SEM}=$ standard error of a mean.

${ }^{d} d f=$ degrees of freedom for error. Where there are two numbers, the first one is for rhizosphere data, and the second one for bulk soil data.

${ }^{\mathrm{e}} \mathrm{NA}=$ not applicable because rhizosphere samples were not collected in the fall after crop harvest. 
Table 5. Analysis of variance summary of legume residue effects on $\beta$-glucosidase enzyme activity during wheat (2008), canola (2009) and barley (2010) crops grown after legumes (2007)

\begin{tabular}{|c|c|c|c|c|c|c|}
\hline \multirow[t]{2}{*}{ Effect } & \multicolumn{2}{|c|}{ Wheat } & \multicolumn{2}{|c|}{ Canola } & \multicolumn{2}{|c|}{ Barley } \\
\hline & Rhizo $^{a}$ & Bulk soil & Rhizo & Bulk soil & Rhizo & Bulk soil \\
\hline & \multicolumn{6}{|c|}{ P values } \\
\hline \multicolumn{7}{|c|}{ Crop residue effects (all treatments in which aboveground residues were returned) } \\
\hline Crop residue $(C)\left(15,18 \mathrm{df}^{\mathrm{b}}\right)$ & 0.590 & 0.027 & $<0.001$ & 0.001 & 0.063 & $<0.001$ \\
\hline Sampling time $(\mathrm{T})$ (18 df) & $N A^{c}$ & 0.003 & NA & $<0.001$ & NA & $<0.001$ \\
\hline $\mathrm{C} \times \mathrm{T}(18 \mathrm{df})$ & NA & 0.088 & NA & 0.940 & NA & 0.212 \\
\hline \multicolumn{7}{|c|}{ Aboveground pea residue removal effects (Treatments 1-4) } \\
\hline Pea type (P) (3 df) & 0.717 & 0.563 & 0.092 & 0.071 & 0.675 & 0.150 \\
\hline Residue removal (R) (6 df) & 0.088 & 0.565 & 0.257 & 0.929 & 0.941 & 0.041 \\
\hline$P \times R(6 d f)$ & 0.246 & 0.646 & 0.426 & 0.796 & 0.625 & 0.090 \\
\hline $\mathrm{T}(12 \mathrm{df})$ & NA & 0.002 & NA & $<0.001$ & NA & $<0.001$ \\
\hline$P \times T(12 d f)$ & NA & 0.977 & NA & 0.357 & NA & 0.573 \\
\hline$R \times T(12 d f)$ & NA & 0.410 & NA & 0.309 & NA & 0.720 \\
\hline$P \times R \times T(12 d f)$ & NA & 0.347 & NA & 0.092 & NA & 0.158 \\
\hline
\end{tabular}

${ }^{\mathrm{a}}$ Rhizo $=$ rhizosphere.

${ }^{b} d f=$ degrees of freedom for error. Where there are two numbers, the first one is for rhizosphere data, and the second one for bulk soil data.

${ }^{\mathrm{c}} \mathrm{NA}=$ not applicable because rhizosphere samples were not collected in the fall after crop harvest. 
Table 6. $\beta$-glucosidase enzyme activity during wheat (2008), canola (2009) and barley (2010) crops grown after legumes (2007) in the treatments where residues were returned

\begin{tabular}{|c|c|c|c|c|c|c|}
\hline \multirow[t]{3}{*}{ Treatment } & \multicolumn{2}{|c|}{ Wheat } & \multicolumn{2}{|c|}{ Canola } & \multicolumn{2}{|c|}{ Barley } \\
\hline & Rhizo $^{\mathrm{a}}$ & Bulk soil & Rhizo & Bulk soil & Rhizo & Bulk soil \\
\hline & \multicolumn{6}{|c|}{$\beta$-glucosidase activity (mg nitrophenol kg ${ }^{-1}$ soil $^{-1}$ ) } \\
\hline \multicolumn{7}{|l|}{ Crop residues } \\
\hline Forage pea & $372 a$ & $324 b$ & $293 d$ & $278 c$ & $310 a$ & $319 b$ \\
\hline Green pea & $371 a$ & $335 b$ & $310 c d$ & $313 b c$ & $308 a$ & $330 b$ \\
\hline Faba bean & $418 a$ & $432 a$ & $425 a$ & $376 a$ & $370 a$ & $452 a$ \\
\hline Faba $G^{b}$ & $413 a$ & $423 a$ & $363 b$ & $363 a b$ & $338 a$ & $454 a$ \\
\hline Vetch GM & $413 a$ & $382 a b$ & $354 b c$ & $311 b c$ & $358 a$ & $418 a$ \\
\hline Barley & $380 a$ & $322 b$ & $353 b c$ & $300 c$ & $316 a$ & $360 b$ \\
\hline $\operatorname{SEM}^{c}\left(15,18 d f^{d}\right)$ & 25.7 & 27.4 & 15.2 & 17.9 & 16.2 & 18.7 \\
\hline \multicolumn{7}{|l|}{ Sampling time } \\
\hline Summer & $N A^{e}$ & $350 b$ & NA & $285 b$ & NA & $336 b$ \\
\hline Fall & NA & $389 a$ & NA & $362 a$ & NA & $442 a$ \\
\hline SEM (18 df) & NA & 8.1 & NA & 17.9 & NA & 8.0 \\
\hline \multicolumn{7}{|l|}{ Contrasts } \\
\hline Legumes vs Barley & 0.542 & 0.072 & 0.825 & 0.175 & 0.259 & 0.108 \\
\hline Pulse crops vs GM & 0.284 & 0.134 & 0.271 & 0.389 & 0.221 & 0.001 \\
\hline Forage pea vs Green pea & 0.973 & 0.785 & 0.441 & 0.180 & 0.932 & 0.675 \\
\hline Faba bean vs Faba GM & 0.898 & 0.831 & 0.012 & 0.596 & 0.176 & 0.940 \\
\hline
\end{tabular}

Note: Means followed by the same letter in a column (within a treatment group) are not significantly different at $P=0.05$. 
${ }^{\mathrm{a}}$ Rhizo $=$ rhizosphere

${ }^{\mathrm{b}} \mathrm{GM}=$ green manure.

${ }^{\mathrm{c}} \mathrm{SEM}=$ standard error of a mean.

${ }^{d} d f=$ degrees of freedom for error. Where there are two numbers, the first one is for rhizosphere data, and the second one for bulk soil data.

${ }^{\mathrm{e}} \mathrm{NA}=$ not applicable because rhizosphere samples were not collected in the fall after crop harvest. 
Table 7. Analysis of variance summary of legume residue effects on physiological diversity of bacteria during wheat (2008), canola (2009) and barley (2010) crops grown after legumes (2007)

\begin{tabular}{|c|c|c|c|c|c|c|}
\hline \multirow[t]{2}{*}{ Effect } & \multicolumn{2}{|c|}{ Wheat } & \multicolumn{2}{|c|}{ Canola } & \multicolumn{2}{|c|}{ Barley } \\
\hline & $i z o^{a}$ & Bulk soil & Rhizo & Bulk soil & Rhizo & Bulk s \\
\hline & \multicolumn{6}{|c|}{ P values } \\
\hline \multicolumn{7}{|c|}{ Crop residue effects (all treatments in which aboveground residues were returned) } \\
\hline Crop residue $(C)\left(15,18 \mathrm{df}^{\mathrm{b}}\right.$ & 0.072 & 0.681 & 0.877 & 0.102 & 0.173 & 0.501 \\
\hline Sampling time $(\mathrm{T})$ (18 df) & $N A^{c}$ & 0.054 & NA & 0.045 & NA & 0.005 \\
\hline $\mathrm{C} \times \mathrm{T}(18 \mathrm{df})$ & NA & 0.009 & NA & 0.903 & NA & 0.334 \\
\hline
\end{tabular}

Aboveground pea residue removal effects (Treatments 1-4)

\begin{tabular}{|c|c|c|c|c|c|c|}
\hline Pea type (P) (3 df) & 0.134 & 0.934 & 0.799 & 0.549 & 0.677 & 0.565 \\
\hline Residue removal (R) (6 df) & 0.242 & 0.325 & 0.936 & 0.405 & 0.065 & 0.719 \\
\hline$P \times R(6 \mathrm{df})$ & 0.162 & 0.329 & 0.298 & 0.014 & 0.092 & 0.236 \\
\hline $\mathrm{T}(12 \mathrm{df})$ & NA & 0.132 & NA & 0.111 & NA & 0.003 \\
\hline$P \times T(12 d f)$ & NA & 0.716 & NA & 0.821 & NA & 0.115 \\
\hline$R \times T(12 d f)$ & NA & 0.909 & NA & 0.380 & NA & 0.614 \\
\hline$P \times R \times T(12 d f)$ & NA & 0.126 & NA & 0.143 & NA & 0.2 \\
\hline
\end{tabular}

${ }^{\mathrm{a}}$ Rhizo = rhizosphere.

${ }^{b} d f=$ degrees of freedom for error. Where there are two numbers, the first one is for rhizosphere data, and the second one for bulk soil data.

${ }^{\mathrm{c}} \mathrm{NA}=$ not applicable because rhizosphere samples were not collected in the fall after crop harvest. 
Table 8. Physiological diversity (Shannon index, $\mathrm{H}^{\prime}$, log scale) of bacteria during wheat (2008), canola (2009) and barley (2010) crops grown after legumes (2007) in the treatments where residues were returned

\begin{tabular}{|c|c|c|c|c|c|c|}
\hline \multirow[t]{3}{*}{ Treatment } & \multicolumn{2}{|c|}{ Wheat } & \multicolumn{2}{|c|}{ Canola } & \multicolumn{2}{|c|}{ Barley } \\
\hline & Rhizo $^{\mathrm{a}}$ & Bulk soil & Rhizo & Bulk soil & Rhizo & Bulk soil \\
\hline & \multicolumn{6}{|c|}{ (Shannon index, $\mathrm{H}^{\prime}$ ) } \\
\hline \multicolumn{7}{|l|}{ Crop residues } \\
\hline Forage pea & $2.49 a$ & $1.97 a$ & $1.96 a$ & $2.28 a$ & $1.70 a$ & $2.12 a$ \\
\hline Green pea & $2.16 a$ & $1.82 a$ & $2.15 a$ & $1.81 a$ & $2.00 a$ & $1.76 a$ \\
\hline Faba bean & $2.42 a$ & $2.03 a$ & $2.23 a$ & $2.07 a$ & $2.34 a$ & $1.66 a$ \\
\hline Faba $\mathrm{GM}^{\mathrm{b}}$ & $2.42 a$ & $1.82 a$ & $2.12 a$ & $2.04 a$ & $2.19 a$ & $1.88 a$ \\
\hline Vetch GM & $2.63 a$ & $2.17 a$ & $2.27 a$ & $2.02 a$ & $1.76 a$ & $1.98 a$ \\
\hline Barley & $2.62 a$ & $1.88 a$ & $2.18 a$ & $1.82 a$ & $2.18 a$ & $1.83 a$ \\
\hline $\operatorname{SEM}^{c}\left(15,18 d f^{d}\right)$ & 0.109 & 0.173 & 0.191 & 0.118 & 0.192 & 0.220 \\
\hline \multicolumn{7}{|l|}{ Sampling time } \\
\hline Summer & $N A^{e}$ & $1.85 a$ & NA & $1.88 b$ & NA & $2.26 a$ \\
\hline Fall & NA & $2.05 a$ & NA & $2.13 a$ & NA & $1.49 b$ \\
\hline SEM (18 df) & NA & 0.066 & NA & 0.084 & NA & 0.145 \\
\hline \multicolumn{7}{|l|}{ Contrasts } \\
\hline Legumes vs Barley & 0.117 & 0.658 & 0.862 & 0.103 & 0.403 & 0.847 \\
\hline Pulse crops vs GM & 0.108 & 0.745 & 0.651 & 0.850 & 0.805 & 0.678 \\
\hline Forage pea vs Green pea & 0.046 & 0.542 & 0.509 & 0.012 & 0.272 & 0.258 \\
\hline Faba bean vs Faba GM & 1.000 & 0.395 & 0.689 & 0.859 & 0.571 & 0.494 \\
\hline
\end{tabular}


Note: Means followed by the same letter in a column (within a treatment group) are not significantly different at $P=0.05$.

${ }^{\mathrm{a}}$ Rhizo $=$ rhizosphere.

${ }^{\mathrm{b}} \mathrm{GM}=$ green manure.

${ }^{\mathrm{c}} \mathrm{SEM}=$ standard error of a mean.

${ }^{d} d f=$ degrees of freedom for error. Where there are two numbers, the first one is for rhizosphere data, and the second one for bulk soil data.

${ }^{\mathrm{e}} \mathrm{NA}=$ not applicable because rhizosphere samples were not collected in the fall after crop harvest. 


\section{Figure Captions}

Fig. 1. Ordination by principal component analysis (PCA) of $C$ substrate utilization profiles of bulk soil bacteria in different crop residue treatments (where residues were returned) in the fall after canola harvest in 2009 (a), and of barley bulk soil at flag leaf growth stage in 2010 (b). GM = green manure. The percentage of total variance explained by each axis is shown. The main BIOLOG substrates whose utilization accounted for the separation of treatments are shown diagonally. Each data point is a mean of 4 replicates.

Fig. 2. Relationship between the initial $C: N$ ratios of decomposing crop residues and $M B C$ in summer in bulk soil under barley, the third subsequent crop. $G M=$ green manure. The four data points for each treatment are replicates.

Fig. 3. Relationship between rhizosphere soil $\beta$-glucosidase enzyme activity and $N$ uptake by wheat, the first subsequent crop, in treatments where residues were returned. $G M=$ green manure. The four data points for each treatment are replicates. Wheat $\mathrm{N}$ uptake data were for the $0 \mathrm{~kg} \mathrm{~N} \mathrm{ha}^{-1}$ rate because soil microbial characteristics were determined at this $\mathrm{N}$ rate. The highest $\mathrm{N}$ uptake (100\%) was $100 \mathrm{~kg} \mathrm{~N}$ ha' 1. 
Fig. 1

(a) 2009 bulk soil - after canola harvest

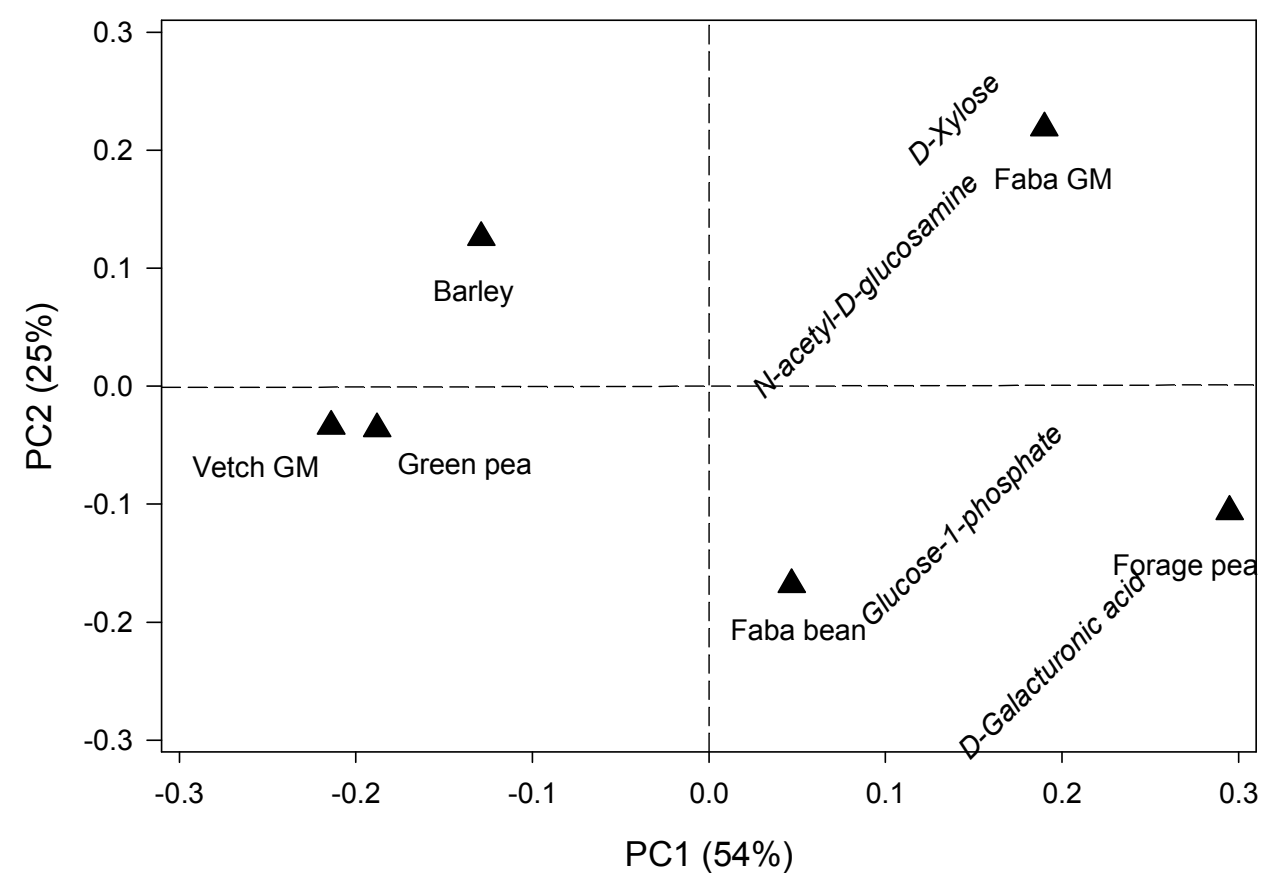

(b) 2010 bulk soil - barley flag leaf stage

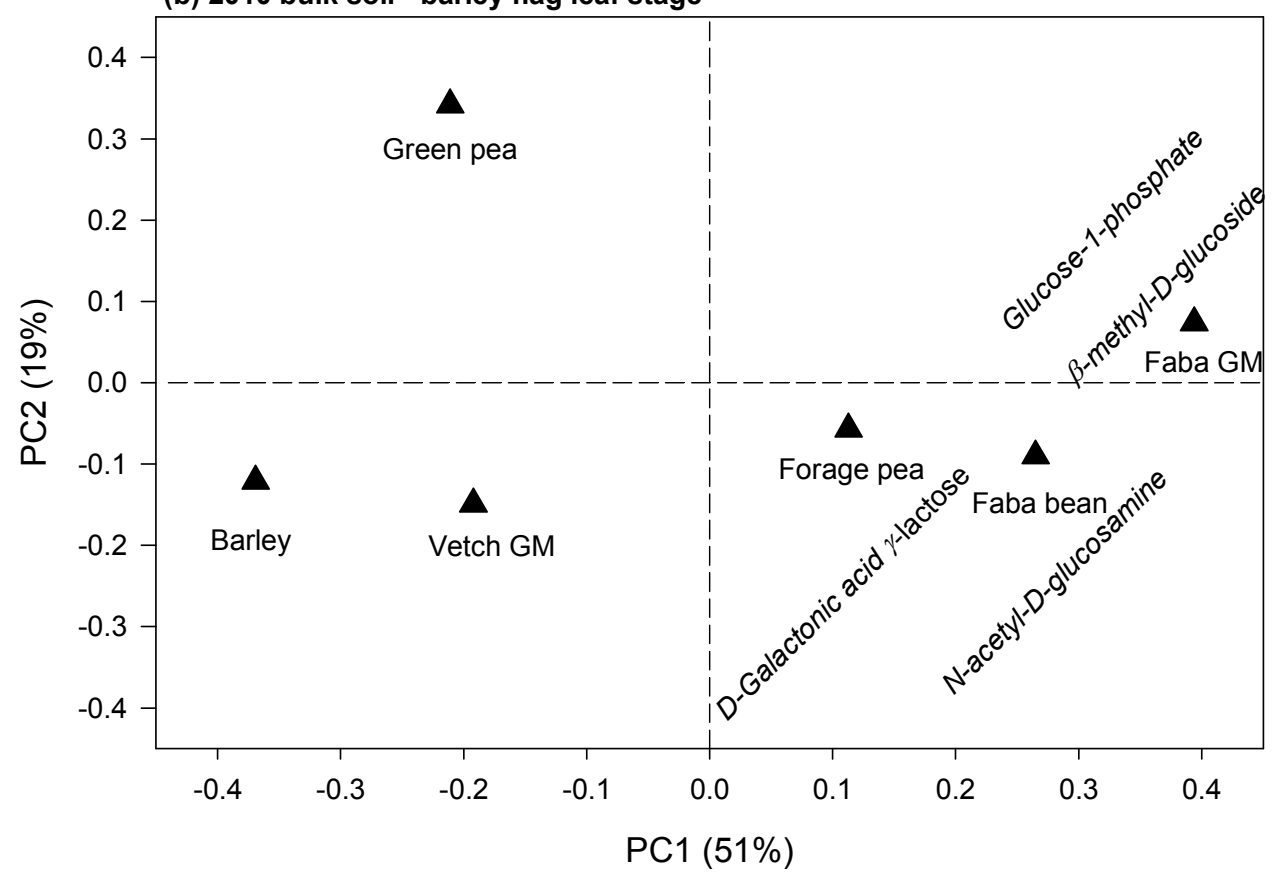


Fig. 2

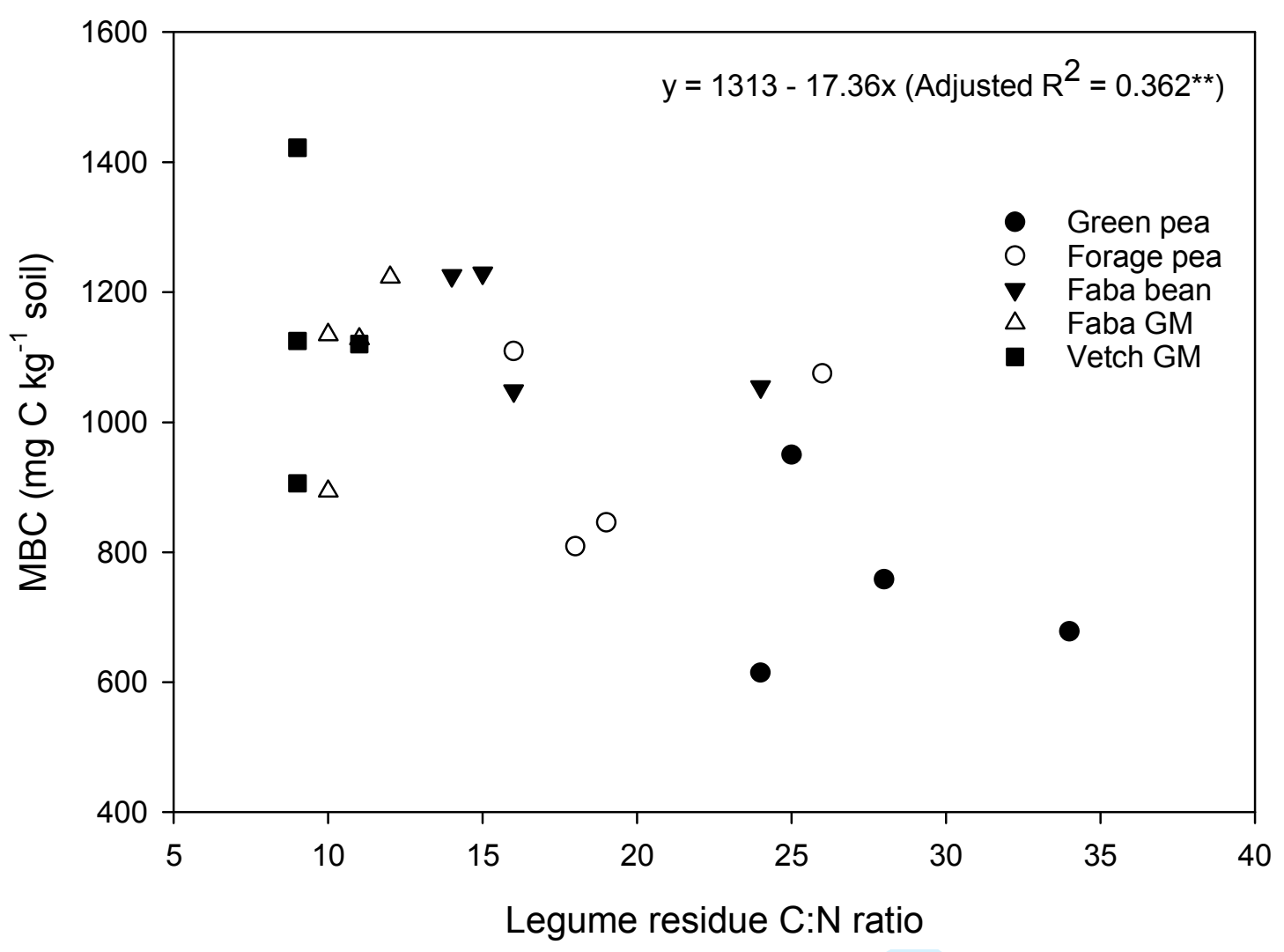


Fig. 3

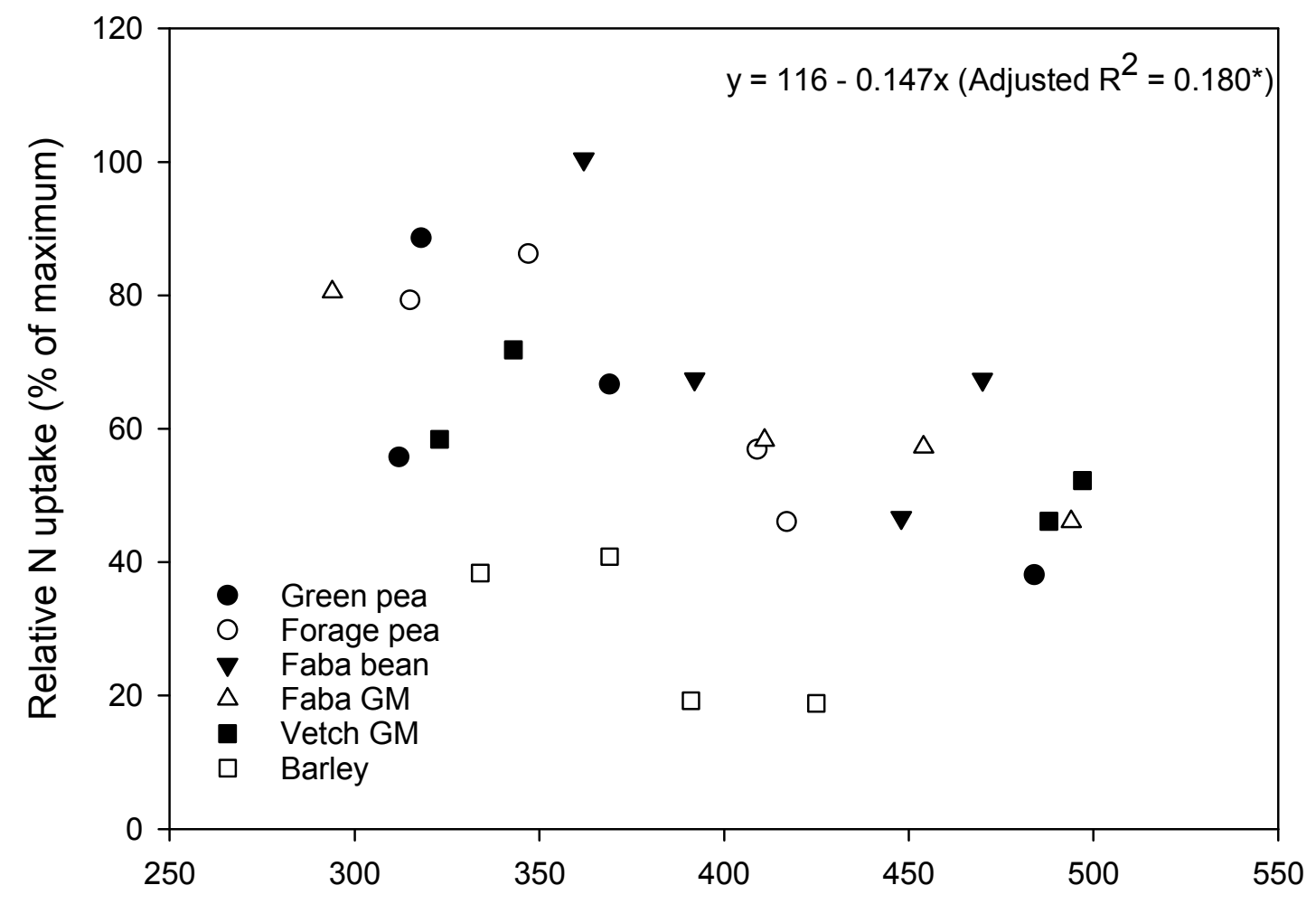

$\beta$-glucosidase activity (mg nitrophenol $\mathrm{kg}^{-1}$ soil $^{-1}$ ) in wheat rhizosphere 